Journal of Sustainamle Agricultural Sciences
http://jsas.journals.ekb.eg/

\title{
Preparation of Functional Foods Free of Gluten for Celiac Disease Patients
}

\author{
E. G. El-Dreny ${ }^{1}$, and G. S. El-Hadidy ${ }^{2 *}$ \\ ${ }^{1}$ Special Food and Nutrition Dep., ${ }^{2}$ Bread and Pasta Dep., Food Tech. Res. Inst., \\ Agric. Res. Center, Egypt
}

\begin{abstract}
$\mathbf{T}$ HE PRESENT investigation was carried out to prepare gluten free biscuits and flat bread with high quality for celiac patients. The raw materials used in this study were desi chickpea, rice flour, common beans and wheat flour $72 \%$ extraction as well as other ingredients used to prepare biscuits and flat bread. Chemical composition, minerals, amino acid of raw materials were determined. Also, determination of chemical composition for biscuits and flat bread blends showed that protein, ether extract, ash and fiber contents were higher in all samples prepared using rice, desi chickpea and common beans flours than those of the sample prepared using wheat flour. Gluten free biscuits and flat bread in all blends had the higher value of all determined minerals except zinc compared to the samples made from wheat flour $72 \%$ extraction. Thickness, volume and weight of gluten free biscuits decreased but spread ratio increased compared to wheat flour biscuits. Caloric values of biscuits and flat bread samples contained desi chickpea and common beans were lower than the control. Appearance and color of biscuits contained desi chickpea and common beans have higher scores than control. Although, all sensory characteristics of flat bread samples prepared using desi chickpea and common beans were somewhat lower than control, the samples were acceptable for the consumers.
\end{abstract}

Key words: Gluten free, Rice flour, Desi chickpea, Common beans, Celiac

\section{Introduction}

Functional food is food comparative in appearance to customary nourishment, which is expended as a part of the typical eating regimen and has shown physiological advantage and decreases the danger of incessant illness past fundamental wholesome capacities (Roberfroid, 2002). Nowadays, there is a growing interest production for gluten-free as the number of Celiac disease (CD) grows. Celiac patient is a digestive disorder which damages, tiny hair like prediction in the little intestine that ingest nutrients due to an immunological response to gluten (Barada et al., 2010). Celiac disease (CD) cannot tolerate the gliadin part of wheat and protamine of rye, oat and barley. The only solution to solve this problem is to follow a hard gluten-free diet throughout long of life.

Celiac disease is an immune system and interminable issue in which the mucous membrane of the small digestive tract is harmed in gluten- intolerant individuals people. Celiac disease is brought about by not just a response to gliadin in wheat protamine yet in addition high molecular glutenin and subunits of gluten protein consequents in harm and aggravation to the small digestive tract and causes ailing health. One individual out of 200 has been determined to have this malady and a few studies have expressed that the prevailing of this infection is 1 out of 100 around the world. This ceaseless malady is perceived as long-life sickness and the main arrangement is adherence tenacity to sans gluten items. In any case, this isn't simple the same number of foodstuffs contain gluten(Motrena et al., 2011).

Offer celiac ailment testing in adolescents and children with the accompanying generally unexplained side effects and signs: incessant 
stomach torment, cramping or distension, interminable or irregular loose bowels, growth failure, iron inadequacy sickliness, weight reduction, constant weakness, short stature, deferred adolescence, osteoporosis and clarified strange liver organic chemistry (Husby et al., 2012).

Rice is the principle staple nourishment for some, nations, giving $20 \%$ of the food energy supply on the world and a good source of B vitamins (riboflavin, thiamine and niacin). As indicated by its amino acids profile, rice has high substance of aspartic and glutamic acids, lysine being the restricting amino acid (FAO, 2004). Because of its low protamine substance and hypoallergenic character, vapid taste, low sodium substance and high substance of effectively absorbable sugars, it has become a grain particularly appropriate not exclusively to get ready sans gluten-free food yet in addition unique weight control plans (Phimolsiripol et al. 2012 and Hamada et al., 2013).

Chickpea (Cicer arietinum L.) is one of the most established and most generally expended vegetable on the planet because of moderately high protein content and wide versatility as a nourishment grain. It is the second most generally developed vegetable on the planet (FAO, 2008). Chickpeas are great wellspring of protein and carbohydrate. Its protein quality is superior to different vegetables, for example, pigeon pea, dark gram and green gram (Kaur and Singh, 2005).

Common beans (Phaseolus vulgaris) are considered as a decent wellspring of high protein content, carbohydrates, dietary fiber and some vitamins and minerals. In addition to these nutritional components, common beans are wealthy in an assortment of a few phytochemicals with potential medical advantages,for example, polyphenol mixes, fiber, lectins and trypsin inhibitors, among others (Reynoso-Camacho et al., 2006).

Biscuits are ready-to-eat, convenient and cheap snack that are consumed by all age groups in many countries (Bolarinwa et al., 2016).Bread is a main diet that is consumed workaday and its quality and sensory evaluation are highly significant by consumers. But the goodness of the gluten-free bread probablybe different than traditionalistic heat bread due to lack of gluten (Motrena et al., 2011).
This investigation aimed to study the use of the broken rice, Desi chickpeas and common beans flour for the development of gluten-free biscuits and flat bread for people suffering from celiac disease.

\section{Materials and Methods}

\section{Materials}

Desi chickpea, common beans, rice ,72\% wheat flour and other ingredients that used to prepare biscuits and flat bread such as egg, baking powder, salt and butter were purchased from the local market, Dakahlia, Egypt. Chemicals and solvents were purchased from EL- Gomhoria Company, Cairo, Egypt.

\section{Preparation of raw materials}

Desi chickpeas and common beans samples were deliberately cleaned from impurities, and afterward washed with faucet water. They were soaked in tap water for $12 \mathrm{hr}$ at room temperature $(25 \pm 2 \mathrm{C})$ according to Khattab and Arntfield, (2009). Soaked samples were dried inoven at $45 \mathrm{C} \pm 5$ for $18 \mathrm{hr}$. All the prepared samples of dried desi chickpeas, common beans and broken rice were grounded into fine flour utilizing an electric Brabender Duisburg roller mill, Germany and were kept in polyethylene bags and stored in at refrigerator till utilizing according to Prasad et al. (2012).

\section{Preparation of products}

Flat bread

Flat bread was composed according to straight-dough method for Aly and Hinar (2015).

\section{Biscuits}

The biscuit mixture is shown in Table 1. It is described according to the methods by Oyewole et al. (1996). Sugar and Butter were blended in (a Kenwood blender) at a medium speed until plumped cream was formed, adjust egg and continue the blending. Desi chickpeas,common beans, rice flour, were lingeringly added to the blender then salivate on a flat rolling board. biscuits were cut, placed on creamed baking trays and baked in an electric oven at $160 \mathrm{C}$ for $15 \mathrm{~min}$.

\section{Proximate analysis of ingredients and biscuits}

Rice flour, desi chickpeas, common beans, flat bread and biscuits were analyzed for moisture, protein, ash, ether extract and crude fiber according to the methods of AOAC (2005). Available carbohydrates were calculated by difference.

Available carbohydrates $=100-($ protein + ash + ether extract + crude fiber)

Total calories were calculated by the formula of 
TABLE 1. Formulation for added ingredients for flat bread and biscuits

\begin{tabular}{lccccccccccc}
\hline & \multicolumn{3}{c}{ Flat bread } & \multicolumn{1}{c}{ Biscuits } \\
\hline Ingredients & 1 & 2 & 3 & 4 & 5 & 6 & 1 & 2 & 3 & 4 & 5 \\
\hline Wheat flour & 100 & 0 & 0 & 0 & 0 & 0 & 100 & 0 & 0 & 0 & 0 \\
Rice flour & 0 & 100 & 80 & 80 & 80 & 80 & 0 & 50 & 50 & 50 & 50 \\
Desi chickpea & 0 & 0 & 20 & 15 & 10 & 5 & 0 & 50 & 40 & 30 & 20 \\
Common beans & 0 & 0 & 0 & 5 & 10 & 15 & 0 & 0 & 10 & 20 & 30 \\
Arabic Gum & 0.1 & 0.1 & 0.1 & 0.1 & 0.1 & 0.1 & 0 & 0 & 0 & 0 & 0 \\
Salt & 1 & 1 & 1 & 1 & 1 & 1 & 0 & 0 & 0 & 0 & 0 \\
Sugar & 0 & 0 & 0 & 0 & 0 & 0 & 85 & 85 & 85 & 85 & 85 \\
Whole egg & 0 & 0 & 0 & 0 & 0 & 0 & 52 & 52 & 52 & 52 & 52 \\
Baking powder & 0 & 0 & 0 & 0 & 0 & 0 & 5 & 5 & 5 & 5 & 5 \\
Butter & 2 & 2 & 2 & 2 & 2 & 0 & 80 & 80 & 80 & 80 & 80 \\
Warm water(ml) & & & & & & As needed & & & &
\end{tabular}

James (1995) as follows:

Total calories $=$ Fat x $9+$ Protein $\times 4+$ Available carbohydrate $\mathrm{x} 4$.

\section{Determination of minerals content}

Minerals were analyzed according to the methods of AOAC (2005).

\section{Determination of amino acids}

Amino acids were calculated according the method described in AOAC (2005).

\section{Sensory evaluation of biscuits}

Biscuit samples were organoleptically evaluated for their sensory characteristics according to the method of Alsenaien et al. (2015). Samples were scored for appearance, color, odor, texture, taste and overall acceptabilityby ten trained panelists form Food Technology Research Institute.

\section{Hardness of biscuits}

Hardness of biscuits was measured according to the methods of AACC (2002)

\section{Physical characteristics of biscuits}

Width and length: six biscuits were put edge to edge and their all-out width was estimated with a Vernier caliper $(0.01 \mathrm{~mm}$ accuracy). The average width was controlled by taking the mean value (Nouma, 2003). Likewise, the biscuits length was determined by putting butt of six biscuits and taking the mean value

\section{Thickness}

Thickness was estimated by stacking six biscuits on the highest point of one another and taking average thickness $(\mathrm{cm})$. Weight of biscuits was estimated as average of estimations of six biscuits with the assistance of advanced weighting balance.

Volume

Volume of biscuits was calculated using length. Width and thickness using the following formula: Volume $\left(\mathrm{m}^{3}\right)=\mathrm{L} \mathrm{X} \mathrm{W} \mathrm{X} \mathrm{T}$

$\mathrm{L}=$ average length of biscuits $(\mathrm{cm})$

$\mathrm{W}=$ average width of biscuits $(\mathrm{cm})$

$\mathrm{T}=$ average thickness of biscuits $(\mathrm{cm})$

\section{Spread ratio}

The spread ratio was evaluated according to Akubor and Ukwuru (2003). by using the following equations: Spread ratio $=$ width / thickness

\section{Organoleptic Evaluation of Flat bread}

Flat bread samples were organoleptically assessed for theirtangible qualities. Half slice of each bread sample was served for ten specialists on white, scent and expendable plates. Samples were scored for, taste, chewing ability, texture, aroma, color and overall acceptability using a score from 1 to 10. The assessment was completed by the strategy for (Land and Shepherd1988).

\section{Statistical analyses}

The expository information were analyzed using SPSS 16.0 programming. Means and standard deviations were resolved utilizing expressive insights. Examinations between samples were resolved utilizing investigation of single direction fluctuation (ANOVA) as per(AboAllam, 2003)and multiple range tests, Statistical significance was defined at $\mathrm{P} \leq 0.05$. 


\section{Results and Discussion}

The analysis of raw materials, shown in Table 2 , revealed that desi chickpea contained $20.69 \%$ crude protein; $6.50 \%$ ether extract; $2.89 \%$ ash; $18.70 \%$ fiber and $51.22 \%$ available carbohydrates. These results agree with (Kohajdova et al., 2011). They reported desi chickpea to contain $20.64 \%$ crude protein; $5.95 \%$ ether extract; $2.88 \%$ ash and $47.83 \%$ available carbohydrates. As for rice flour, results showed $7.95 \%$ crude protein, $0.67 \%$ ether extract, $0.93 \%$ ash, 0.32 fiber and $90.13 \%$ available carbohydrates. These results were agreement with Omran and Hussien(2015) reported that rice flour had $7.78 \%$ proteins, $0.21 \%$ crude fiber, $0.66 \%$ ash and $91.36 \%$ carbohydrates. (Roushdiet al. 2016) studied that rice flour had $6.65 \%$ proteins, $0.38 \%$ crude fiber, $0.54 \%$ ash and $91.37 \%$ available carbohydrates. Results of common beans analysis indicated that crude protein was $24.5 \%$, ether extract reached $1.27 \%$, While fiber was $2.83 \%$, ash was $2.9 \%$ and available carbohydrates were $68.50 \%$. These results are consistent with the work of Rezende et al. (2018) who reported that common beans had $22 \%$ protein, $2 \%$ ether extract, $3 \%$ ash and $66 \%$ carbohydrates.

\section{Minerals content of Desi chickpea, Rice flour and} Common beans

Table 3 presents mineral composition of the desichickpea flour revealed that desi chickpea contained $178 \mathrm{mg} / 100 \mathrm{~g}$ calcium, $27.53 \mathrm{mg} / 100 \mathrm{~g}$ sodium, $163.77 \mathrm{mg} / 100 \mathrm{~g}$ magnesium, 1120 $\mathrm{mg} / 100 \mathrm{~g}$ potassium, $5.18 \mathrm{mg} / 100 \mathrm{~g}$ manganese, 6.50 $\mathrm{mg} / 100 \mathrm{~g}$ iron and $3.32 \mathrm{mg} / 100 \mathrm{~g}$ zinc. These results for desi chickpea agreemed with the work of Ghribi et al. (2015) who reported that desi chickpea had calcium, sodium, magnesium, manganese, zinc and iron content of 177, 7.35, 133.63, 3.71, 3.32 and $4.86 \mathrm{mg} / 100 \mathrm{~g}$, respectively, for chickpea seeds. The observed variation could be explained by various factors such as variety, soil type and treatment type. The results in Table 3 revealed that rice flour contained $17.3 \mathrm{mg} / 100 \mathrm{~g}$ calcium, $7.00 \mathrm{mg} / 100 \mathrm{~g}$ sodium, $143 \mathrm{mg} / 100 \mathrm{~g}$ magnesium, $375.86 \mathrm{mg} / 100 \mathrm{~g}$ potassium, $2.30 \mathrm{mg} / 100 \mathrm{~g}$ manganese, $1.85 \mathrm{mg} / 100 \mathrm{~g}$ iron and $0.98 \mathrm{mg} / 100 \mathrm{~g}$ zinc. These results were different from the work by Ibrahim (2017) who found that rice flour contains $9.56 \mathrm{mg} / 100 \mathrm{~g}$ calcium, $0.56 \mathrm{mg} / 100 \mathrm{~g}$ iron and $0.42 \mathrm{mg} / 100 \mathrm{~g}$ zinc. Also, Anjum et al. (2007) who reported that rice flour had manganese, zinc and iron content of $2.3,1.44$ and $1.74 \mathrm{mg} / 100 \mathrm{~g}$, respectively.

The mineral content of the common beans revealed that they contained $263 \mathrm{mg} / 100 \mathrm{~g}$ calcium, $74 \mathrm{mg} / 100 \mathrm{~g}$ sodium, $119 \mathrm{mg} / 100 \mathrm{~g}$ magnesium, $1759 \mathrm{mg} / 100 \mathrm{~g}$ potassium, 1.15 $\mathrm{mg} / 100 \mathrm{~g}$ manganese, 13.2 iron $\mathrm{mg} / 100 \mathrm{~g}$ and 4.70 $\mathrm{mg} / 100 \mathrm{~g}$ zinc as shown in Table 3 . The obtained results for common beans agree to work by Koute et al. (2018).

TABLE 2. Chemical composition of Desi chickpea, Rice flour and Common beans(on dry weight basis)

\begin{tabular}{lccc}
\hline $\begin{array}{r}\text { Raw materials } \\
\text { Components\% }\end{array}$ & Desi chickpea & Rice flour & Common beans \\
\hline Crude protein & 20.69 & 7.95 & 24.50 \\
Ether extract & 6.50 & 0.67 & 1.27 \\
Ash & 2.89 & 0.93 & 2.9 \\
Fiber & 18.70 & 0.32 & 2.83 \\
Available carbohydrates* & 51.22 & 90.13 & 68.50
\end{tabular}

Available carbohydrates were calculated by difference

TABLE 3. Minerals content of Desi chickpea, Rice flour and Common bean (mg/100g on dry weight basis)

\begin{tabular}{llccc}
\hline & Minerals ((mg/100g) & Desi chickpea & Rice flour & Common bean \\
\hline Calcium & $(\mathrm{Ca})$ & 178 & 17.3 & 263 \\
Sodium & $(\mathrm{Na})$ & 27.53 & 7 & 74 \\
Magnesium & $(\mathrm{Mg})$ & 163.77 & 143 & 119 \\
Potassium & $(\mathrm{K})$ & 1120 & 375.86 & 1759 \\
Manganese & $(\mathrm{Mn})$ & 5.16 & 2.30 & 1.15 \\
Iron & $(\mathrm{Fe})$ & 6.50 & 1.85 & 13.2 \\
Zinc & $(\mathrm{Zn})$ & 3.32 & 0.98 & 4.70 \\
\hline
\end{tabular}


Amino acids composition of desi chickpea, rice flour and common beans

The amino acids composition of desi chickpea, rice flour and common beans was given in Table(4). The results showed that desi chickpea protein was a poor source of cysteine $1.60 \%$, tryptophan $1.30 \%$ and methionine $1.29 \%$. On the other hand,lysine, isoleucine, valine, phenylalanine, tyrosine, threonine, leucine and histidine were the predominate indispensable amino acid represented 7.60, 5.50, $5.30,4.60,3.81,4.70,7.60$ and $3.27 \%$, respectively, while dispensable amino acids contained glutamic and aspartic were $15.09 \%$ and $10.19 \%$ followed by arginine $10.50 \%$, while alanine, glycine, proline and serine represented 4.05, 4.01.3.60 and 6.08\%, respectively. These results agreed with Ghribi et al. (2015) who found that desi chickpea flour is rich in aspartic acid, glutamic acid and arginine, and the total of these three amino acids was $34.53 \mathrm{~g} / 100 \mathrm{~g}$ of protein; also, desi chickpea is rich in essential amino acids lysine, leucine, phenylalanine, valine, tyrosine, threonine, methionine and histidine.

The results for amino acids composition of rice flour protein showed that it was consider a poor source of cysteine $3.60 \%$, tryptophan $1.50 \%$, methionine $2.80 \%$ and histidine $2.90 \%$. On the other hand, lysine, isoleucine, valine, phenylalanine, tyrosine, threonine and leucine were the predominate essential amino acids which represented 3.80, 4.30, 4.47, 8.30, 5.34,
4.76 and $8.50 \%$, respectively, while nonessential amino acids contained glutamic and aspartic were $17.15 \%$ and $9.80 \%$ followed by arginine $7.30 \%$, while alanine, glycine, proline and serine represented $4.60,4.47,0.80$ and $5.20 \%$, respectively. These results agree with Kalman (2014) who found rice containing essential amino acids; lysine, leucine, phenylalanine, valine, tyrosine, threonine, methionine and histidine. Also, rice was rich in glutamic, aspartic and arginine as non-essential amino acids

The results in Table 4 showed that common beans protein was considered a poor source of cysteine $1.40 \%$, tryptophan $1.27 \%$ and methionine $1.50 \%$. On the other hand, lysine, isoleucine, valine, phenylalanine, tyrosine, threonine, leucine and histidine were the predominant essential amino acids which represented 7.50, 5.70, 5.80, 5.75, 2.63, 4.80, 8.40 and $3.80 \%$, respectively, while nonessential amino acids contained glutamic and aspartic were $15.25 \%$ and $13.75 \%$ followed by arginine $6.05 \%$, while alanine, glycine, proline and serine represented $5.04,3.80$. 4.10 and $5.30 \%$, respectively. These results agree with USDA (1986) who found that common beans flour is rich in aspartic acid, glutamic acid and arginine, also common beans flour rich in aspartic acid, glutamic acid and arginine, also common beans isrich in essential amino acids such as lysine, leucine, phenylalanine, valine, tyrosine, threonine, methionine and histidine.

TABLE 4. Amino acids composition of Desi chickpea, Rice flour and Common beans (g. amino acid /100g protein)

\begin{tabular}{lccc}
\hline \multicolumn{1}{c}{ Amino acids(g/100g protein) } & $\begin{array}{c}\text { Desi chickpea } \\
\text { Essential amino acids (EAA) }\end{array}$ & Rice flour & Common bean \\
\hline Lysine & 7.60 & 3.80 & 7.50 \\
Isoleucine & 5.50 & 4.30 & 5.70 \\
Valine & 5.30 & 4.47 & 5.80 \\
Methionine & 1.29 & 2.80 & 1.50 \\
Cystine & 1.60 & 3.60 & 1.40 \\
Phenylalanine & 4.60 & 8.30 & 5.75 \\
Tyrosine & 3.81 & 5.34 & 2.63 \\
Theronine & 4.70 & 4.76 & 4.80 \\
Tryptophan & 1.30 & 1.50 & 1.27 \\
Leucine & 7.60 & 8.50 & 8.40 \\
Histadine & 3.27 & 2.90 & 3.80 \\
& Non-essential amino acids (Non-EAA) & \\
Arginine & 10.50 & 7.30 & 6.00 \\
Alanine & 4.05 & 4.60 & 5.00 \\
Aspartic acid & 10.19 & 9.80 & 13.00 \\
Glutamic acid & 15.00 & 17.15 & 14.25 \\
Glycine & 4.01 & 4.47 & 3.80 \\
Proline & 3.60 & 0.80 & 4.10 \\
Serine & 6.08 & 5.20 & 5.30 \\
\hline
\end{tabular}


Effect of desi chickpea, rice flour and common beans flour on chemical components of gluten free biscuits

The chemical composition of gluten free biscuits prepared of desi chickpea, rice flour and common beans flour and biscuits prepared from $100 \%$ of wheat flour ( $72 \%$ extraction) was studied and the obtained results are shown in Table 5. It was found that crude protein, ether extract, crude fiber and ash increased of gluten free biscuits compared with biscuits prepared from $100 \%$ of wheat flour this may be due to desi chickpea and common beans flours have high amounts of these components compared with wheat flour. Camara et al. (2013)who detailed that common beans (Phaseolus vulgaris L.) or dry beans, have been described as an about impeccable nourishment due to their high protein, prebiotic, fiber, vitamin $B$, and chemically artificially differing micronutrient composition. From the previously mentioned information about the chemical composition of biscuits, it could be showed that the gluten free biscuits had sensible measures of the necessary supplements for youngsters especially protein, fat, $\mathrm{Fe}, \mathrm{Ca}, \mathrm{Zn}$ and energy.

TABLE 5. Chemical composition of glutenfree biscuits

\begin{tabular}{|c|c|c|c|c|c|c|}
\hline $\begin{array}{c}\text { Components } \\
\text { Samples }\end{array}$ & Crude protein & $\begin{array}{c}\text { Ether } \\
\text { extract }\end{array}$ & Crude fiber & Ash & $\begin{array}{c}\text { available } \\
\text { carbohydrates }\end{array}$ & $\mathrm{K} \mathrm{Cal} / 100 \mathrm{gm}$ \\
\hline Control 1 & $14.60 \mathrm{~d}$ & $17.29 \mathrm{e}$ & $0.22 \mathrm{e}$ & $0.35 \mathrm{c}$ & $67.54 \mathrm{a}$ & $484.16 \mathrm{a}$ \\
\hline \multirow{2}{*}{ Blend 2} & $16.30 \mathrm{c}$ & $18.60 \mathrm{a}$ & $5.19 \mathrm{a}$ & $1.06 \mathrm{a}$ & $58.84 d$ & $472.88 \mathrm{c}$ \\
\hline & \pm 0.05 & \pm 0.06 & \pm 0.09 & \pm 0.01 & \pm 0.14 & \pm 0.36 \\
\hline Blend 3 & \pm 0.05 & \pm 0.10 & \pm 0.11 & \pm 0.01 & \pm 0.50 & \pm 1.72 \\
\hline \multirow{2}{*}{ Blend 4} & $16.68 \mathrm{a}$ & $18.19 \mathrm{c}$ & $3.49 \mathrm{c}$ & $1.05 \mathrm{a}$ & $60.59 \mathrm{c}$ & $472.79 b$ \\
\hline & \pm 0.07 & \pm 0.11 & \pm 0.04 & \pm 0.02 & \pm 0.12 & \pm 0.21 \\
\hline Blend 5 & $16.58 \mathrm{ab}$ & $17.89 \mathrm{~d}$ & $2.60 \mathrm{~d}$ & $0.95 b$ & $61.98 b$ & $475.25 b$ \\
\hline
\end{tabular}

- Values followed by the same letter in columns are not significantly different at LSD at $(\mathrm{p} \leq 0.05)$.

-Each value was an average of three determinations \pm standard deviation.

TABLE 6. Minerals content of biscuits prepared from wheat flour, riceflour, desi chickpea and common beans.

\begin{tabular}{|c|c|c|c|c|c|c|c|}
\hline \multirow{2}{*}{$\begin{array}{l}\text { Minerals } \\
\text { Samples }\end{array}$} & \multicolumn{4}{|c|}{ Major elements } & \multicolumn{3}{|c|}{ Trace elements } \\
\hline & $\mathbf{C a}$ & $\mathbf{N a}$ & Mg & $\mathbf{K}$ & Mn & $\mathrm{Fe}$ & $\mathbf{Z n}$ \\
\hline \multirow{2}{*}{ Control 1} & $10.83 \mathrm{e}$ & $3.77 \mathrm{e}$ & $79.60 \mathrm{e}$ & $90.00 \mathrm{e}$ & $1.50 \mathrm{~d}$ & $0.97 \mathrm{e}$ & $1.80 \mathrm{a}$ \\
\hline & \pm 0.21 & \pm 0.15 & \pm 0.53 & \pm 1.00 & \pm 0.10 & \pm 0.01 & \pm 0.21 \\
\hline \multirow{2}{*}{ Blend 2} & $56.25 \mathrm{~d}$ & $10.84 \mathrm{c}$ & $87.99 \mathrm{a}$ & $434.26 \mathrm{~d}$ & $2.25 \mathrm{a}$ & $2.40 \mathrm{~d}$ & $1.27 \mathrm{~d}$ \\
\hline & \pm 0.63 & \pm 0.76 & \pm 0.98 & \pm 0.65 & \pm 0.02 & \pm 0.02 & \pm 0.02 \\
\hline \multirow{2}{*}{ Blend 3} & $61.21 \mathrm{c}$ & $12.40 \mathrm{~b}$ & $85.79 b$ & $470.95 \mathrm{c}$ & $2.02 b$ & $2.81 \mathrm{c}$ & $1.36 \mathrm{~cd}$ \\
\hline & \pm 1.05 & \pm 0.36 & \pm 0.71 & \pm 1.00 & $\pm 0 . .02$ & \pm 0.01 & \pm 0.03 \\
\hline \multirow{2}{*}{ Blend 4} & $65.83 b$ & $9.60 \mathrm{~d}$ & $83.49 \mathrm{c}$ & $506.97 \mathrm{~b}$ & $1.76 \mathrm{c}$ & $3.20 \mathrm{~b}$ & $1.40 \mathrm{c}$ \\
\hline & \pm 0.76 & \pm 0.10 & \pm 0.29 & \pm 0.96 & \pm 0.01 & \pm 0.05 & \pm 0.02 \\
\hline \multirow{2}{*}{ Blend5 } & $71.47 \mathrm{a}$ & $18.50 \mathrm{a}$ & $81.32 \mathrm{~d}$ & $545.0 \mathrm{a}$ & $1.56 \mathrm{~d}$ & $3.59 \mathrm{a}$ & $1.51 \mathrm{~b}$ \\
\hline & \pm 0.50 & \pm 0.40 & \pm 0.17 & \pm 0.58 & $\pm 0 . .05$ & \pm 0.01 & \pm 0.04 \\
\hline
\end{tabular}

- Values followed by the same letter in columns are not significantly different at LSD at ( $\mathrm{p} \leq 0.05)$.

- Each value was an average of three determinations \pm standard deviation.

J. Sus. Agric. Sci. Vol. 46, No. 1 (2020)
Minerals content of biscuits prepared from wheat flour, rice flour, desi chickpea and common beans

The minerals contents of gluten free biscuits blends prepared using rice flour, desi chickpea and common beans and biscuits prepared from 100\% of wheat flour ( $72 \%$ extraction) were analyzed and obtained results are shown in Table 6. It was found thatprepared gluten free biscuits in all blends had higher value of all determined minerals except zinc compared with the biscuit samples made from wheat flour $72 \%$ extraction. This may be due to high contents of calcium, sodium, magnesium, potassium, manganese and iron in desi chickpea flour or common bean flour. While having low contents of zinc in desi chickpea flour or common bean flour compare with wheat flour $72 \%$ extraction. It could be concluded that the addition of common beans or desi chickpea and rice flour improved the minerals content of biscuit. The obtained results are in agreement with the results of Ibrahim (2017). From the previously mentioned information about the minerals composition of obtained gluten free biscuits, it could be exhibited that they had sensible measures of the necessary supplements for children especially $\mathrm{Ca}, \mathrm{K}, \mathrm{Zn}, \mathrm{Mg}$ and $\mathrm{Fe}$. 


\section{Sensory evaluation of gluten free biscuits}

The sensory properties appearance, color, odor, texture, taste and overall acceptability of biscuits prepared from rice flour, desi chickpea and common bean flours of different levels and biscuits prepared from $100 \%$ of wheat flour were evaluated by ten panelists. The obtained results were statistically analyzed and recorded in Table 6. From the data presented in Table 6 , it could be noticed that Appearance and color of biscuits contained desi chickpea and common beans have higher scores than control. The other remain sensory properties of biscuit samples contained desi chickpea and common beans were nearly similar with those of control. Sensory evaluation is considered to be a valuable tool in solving problems involving food acceptability. It is useful in product improvement, quality maintenance and more important in a new products development.

Effect of rice flour, desi chickpea flour and common beans on the physical properties of gluten free biscuits

The results of the physicals properties of gluten free biscuits prepared from rice flour, desi chickpea flour and common bean flour blends are shown in Table 7. The length, width, thickness, and weight significantly $(\mathrm{P} \geq 0.05)$ in all blends of gluten free biscuits prepared from different amount of desi chickpea flour and common beans flour. While biscuits prepared fromrice flour, desi chickpea flour and common beans flour tended to decrease the thickness, weight and volume, but spread ratio increased in compared with those biscuits which prepared from $100 \%$ of wheat flour ( $72 \%$ extraction) control 1 . Such differences in the physical properties could be attributed to properties in the raw materials such as wheat flour, rice flour, desi chickpea flour and common beans flour.Bose and Sham(2010) detailed that Spread ratio is considered as one of the most significant quality parameter of biscuits as it relates with texture, grain artfulness, bite and overall mouth feel of the biscuits. Biscuit spread ratio stand for a ratio of diameter to height. Chauhan et al. (2016) expressed that biscuits having higher spread ratios are viewed as the most alluring mixture with lower viscosity makes cookies to spread at a quicker rate, so subsequently consistency of batter decreases as expansion of white beans flour and expands the spread rate. It is noticed that the spread ratio increment with including of white beans flour and with increment in the protein content of chickpea in the biscuits and it could have been influenced by nonappearance of gluten.

TABLE 7. Sensory evaluation of biscuits

\begin{tabular}{|c|c|c|c|c|c|c|}
\hline Samples & Appearance & Color & Odor & Texture & Taste & Overall acceptability \\
\hline Control & $\begin{array}{l}8.43 \mathrm{~b} \\
\pm 0.10\end{array}$ & $\begin{array}{l}8.53 b \\
\pm 0.11\end{array}$ & $\begin{array}{l}8.68 \mathrm{a} \\
\pm 0.06\end{array}$ & $\begin{array}{l}8.95 \mathrm{a} \\
\pm 0.06\end{array}$ & $\begin{array}{l}8.77 \mathrm{a} \\
\pm 0.07\end{array}$ & $\begin{array}{c}43.36 \mathrm{a} \\
\pm 0.23\end{array}$ \\
\hline Blend 2 & $\begin{array}{l}8.60 \mathrm{~b} \\
\pm 0.10\end{array}$ & $\begin{array}{l}8.94 \mathrm{a} \\
\pm 0.07\end{array}$ & $\begin{array}{l}8.57 \mathrm{a} \\
\pm 0.05\end{array}$ & $\begin{array}{l}8.67 \mathrm{a} \\
\pm 0.07\end{array}$ & $\begin{array}{l}8.42 \mathrm{a} \\
\pm 0.04\end{array}$ & $\begin{array}{c}43.20 \mathrm{a} \\
\pm 0.15\end{array}$ \\
\hline Blend 3 & $\begin{array}{l}9.16 \mathrm{a} \\
\pm 0.30\end{array}$ & $\begin{array}{l}8.95 \mathrm{a} \\
\pm 0.07\end{array}$ & $\begin{array}{l}8.58 \mathrm{a} \\
\pm 0.14\end{array}$ & $\begin{array}{l}8.67 \mathrm{a} \\
\pm 0.29\end{array}$ & $\begin{array}{l}8.67 \mathrm{a} \\
\pm 0.29\end{array}$ & $\begin{array}{c}44.03 \mathrm{a} \\
\pm 0.31\end{array}$ \\
\hline Blend 4 & $\begin{array}{l}8.42 \mathrm{~b} \\
\pm 0.38\end{array}$ & $\begin{array}{c}8.67 \mathrm{ab} \\
\pm 0.25\end{array}$ & $\begin{array}{l}8.78 \mathrm{a} \\
\pm 0.25\end{array}$ & $\begin{array}{l}8.71 \mathrm{a} \\
\pm 0.26\end{array}$ & $\begin{array}{l}8.67 \mathrm{a} \\
\pm 0.29\end{array}$ & $\begin{array}{c}43.25 \mathrm{a} \\
\pm 0.66\end{array}$ \\
\hline Blend 5 & $\begin{array}{c}8.83 \mathrm{ab} \\
\pm 0.29\end{array}$ & $\begin{array}{c}8.67 \mathrm{ab} \\
\pm 0.29\end{array}$ & $\begin{array}{l}8.83 \mathrm{a} \\
\pm 0.29\end{array}$ & $\begin{array}{l}8.67 \mathrm{a} \\
\pm 0.29\end{array}$ & $\begin{array}{l}8.33 \mathrm{a} \\
\pm 0.29\end{array}$ & $\begin{array}{c}43.33 \mathrm{a} \\
\pm 0.57\end{array}$ \\
\hline
\end{tabular}

- Values followed by the same letter in columns are not significantly different at LSD at ( $\mathrm{p} \leq 0.05)$.

-Each value was an average of three determinations \pm standard deviation.

TABLE 7. Physical properties of gluten free biscuit

\begin{tabular}{|c|c|c|c|c|c|c|}
\hline Samples & Length & Width & Thickness & Spread ratio & Weight & Volume \\
\hline Control1 & $\begin{array}{c}10.26 \mathrm{a} \\
\pm 0.36\end{array}$ & $\begin{array}{l}3.23 \mathrm{a} \\
\pm 0.14\end{array}$ & $\begin{array}{l}0.85 \mathrm{a} \\
\pm 0.03\end{array}$ & $\begin{array}{l}3.80 \mathrm{~b} \\
\pm 0.24\end{array}$ & $\begin{array}{l}11.08 \mathrm{a} \\
\pm 0.18\end{array}$ & $\begin{array}{c}28.31 \mathrm{a} \\
\pm 1.40\end{array}$ \\
\hline Blend 2 & $\begin{array}{l}10.09 \mathrm{a} \\
\pm 0.21\end{array}$ & $\begin{array}{l}3.10 \mathrm{a} \\
\pm 0.10\end{array}$ & $\begin{array}{l}0.73 \mathrm{~b} \\
\pm 0.03\end{array}$ & $\begin{array}{l}4.23 \mathrm{a} \\
\pm 0.02\end{array}$ & $\begin{array}{c}10.25 b \\
\pm 0.15\end{array}$ & $\begin{array}{c}22.97 \mathrm{~b} \\
\pm 1.60\end{array}$ \\
\hline Blend 3 & $\begin{array}{l}9.88 \mathrm{a} \\
\pm 0.08\end{array}$ & $\begin{array}{l}3.20 \mathrm{a} \\
\pm 0.10\end{array}$ & $\begin{array}{l}0.75 \mathrm{~b} \\
\pm 0.02\end{array}$ & $\begin{array}{l}4.25 \mathrm{a} \\
\pm 0.28\end{array}$ & $\begin{array}{c}10.47 b \\
\pm 0.25\end{array}$ & $\begin{array}{c}23.80 \mathrm{~b} \\
\pm 0.16\end{array}$ \\
\hline Blend 4 & $\begin{array}{l}10.14 \mathrm{a} \\
\pm 0.05\end{array}$ & $\begin{array}{l}3.13 \mathrm{a} \\
\pm 0.15\end{array}$ & $\begin{array}{l}0.75 \mathrm{~b} \\
\pm 0.02\end{array}$ & $\begin{array}{c}4.15 \mathrm{ab} \\
\pm 0.13\end{array}$ & $\begin{array}{c}10.57 \mathrm{~b} \\
\pm 0.06\end{array}$ & $\begin{array}{c}23.97 \mathrm{~b} \\
\pm 2.08\end{array}$ \\
\hline Blend 5 & $\begin{array}{c}10.26 \mathrm{a} \\
\pm 0.13\end{array}$ & $\begin{array}{l}3.23 \mathrm{a} \\
\pm 0.15\end{array}$ & $\begin{array}{l}0.74 \mathrm{~b} \\
\pm 0.02\end{array}$ & $\begin{array}{l}4.41 \mathrm{a} \\
\pm 0.27\end{array}$ & $\begin{array}{c}10.37 \mathrm{~b} \\
\pm 0.15\end{array}$ & $\begin{array}{c}24.82 b \\
\pm 2.14\end{array}$ \\
\hline
\end{tabular}

- Values followed by the same letter in columns are not significantly different at LSD at ( $\mathrm{p} \leq 0.05$ ).

- Each value was an average of three determinations \pm standard deviation. 


\section{Hardness of biscuits}

Data in Fig. 1 presented the textural parameters assessed from texture profile analysis (TPA) test curves results for the biscuits samples. A marked increase in hardness from 44.33 to 60 newtons was observed. On the other hand, the biscuits become increasing amount of using rice flour, desi chickpea and common beans. Data showed that blend No. 2 had the highest hardness value (60 newton) in compared to other samples and control (44.33newton). This may be due to the effect of desi chickpeain formulation. These results agreed with Ibrahim (2017) who detailed that the supplanting $40 \%$ of formulation common beans flour, the hardness of the rolls expanded analyzed control test also revealed that more quality was expected to break cookies joined with legumes flour. This might have come about because of protein rich flour which need more water to obtain good cookie dough, and the cookies arranged from high-assimilation mixture will in general be incredibly hard.

Effect of rice flour, desi chickpea and common beans flour on chemical components of gluten free flat bread

The chemical composition of gluten free flat bread prepared from rice flour, desi chickpea and common beans flour and flat bread prepared from $100 \%$ of rice flour or $100 \%$ of wheat flour ( $72 \%$ extraction) were studied and obtained results are shown in Table 8. It was found that crude protein, crude fat ether extract, crude fiber and ash of flat bread samples prepared using rice, chickpea and common beans flours were higher than those of bread prepared using wheat or rice flour (control 1 and 2). This may be due to high contents of protein, crude fat, crude fiber and ash in desi chickpea flour or common bean flour. While having low contents of total carbohydrates in desi chickpea flour or common bean flour compared with rice and wheat flour (Camara et al., 2013) detailed that common beans (Phaseolus vulgaris L.) or dry beans, have been described as an about impeccable nourishment due to their high protein, prebiotic, fiber, vitamin $\mathrm{B}$, and chemically artificially differing micronutrient composition. From the previously mentioned information about the chemical composition of flat bread, it could be showed that the gluten free flat bread had sensible measures of the necessary supplements for children especiallyprotein, fat, crude fiber and energy.

Minerals content of flat bread prepared from rice flour, desi chickpea and common beans

The minerals contents of gluten free flat bread blends and flat bread prepared from 100\% of wheat flour ( $72 \%$ extraction) was studied and obtained results are shown in Table 9. It was found that calcium, sodium, magnesium, potassium, manganese and iron increased in flat bread samples prepared using desi chickpea flour or common bean flour but zinc decreased compared with control. This may be due to high contents of calcium, sodium, magnesium, potassium, manganese and iron in desi chickpea flour or common beans flour. While having low contents of zinc in desi chickpea flour or common beans flour compared with wheat flour $72 \%$ extraction.

Sensory evaluation of free gluten flat bread

Sensory evaluation scores for the flat bread supplemented with different levels of rice flour, desi chickpea and common beans flour are presented in Table 10. The results revealed that all sensory characteristics of flat bread samples prepared using desi chickpea and common beans were somewhat lower than those of sample prepared using wheat flour (control 1) but all samples were in the acceptable limits for the consumers (scores were more than 8). These results indicate that using of desi chickpea flour at levels 50, 40, 30 and 20\% and common beans flour at levels 10, 20 and $30 \%$ to prepare gluten free bread have a small negative effect on sensory characteristics. As reported by Hanee and Yaseen (2014) sensory evaluation was directed by positioning tests which was created for evaluating the food products worthiness, in which higher the score shows to higher adequacy and quality.

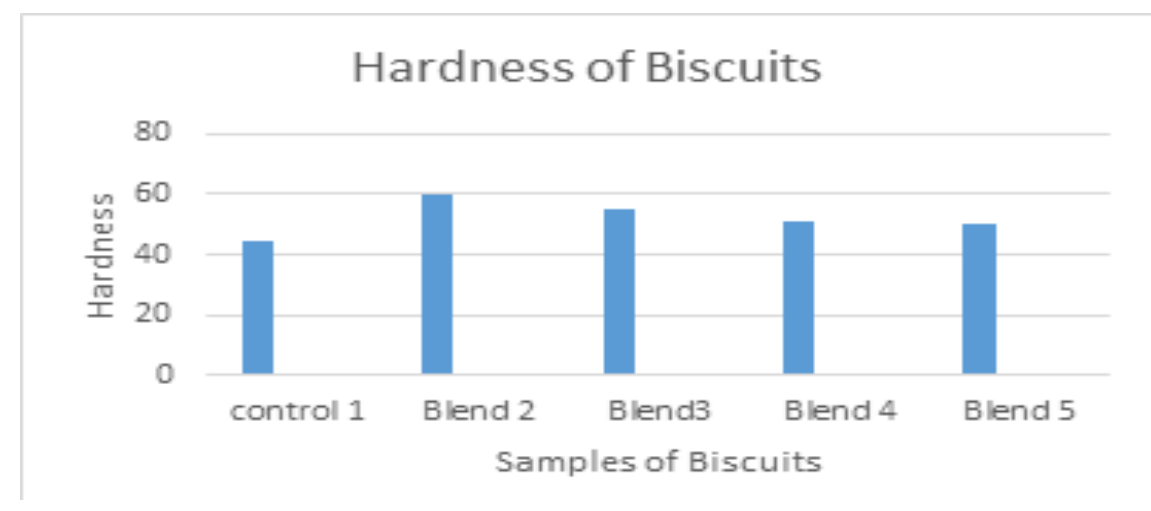

Fig. 1. Hardness of the prepared biscuits samples 
TABLE 8. Chemical components of flat bread made from rice flour, desi chickpea and common beans.

\begin{tabular}{ccccccc}
\hline $\begin{array}{c}\text { Components } \\
\text { Samples }\end{array}$ & Protein & Ash & $\begin{array}{c}\text { Ether } \\
\text { extract }\end{array}$ & $\begin{array}{c}\text { Crude } \\
\text { fiber }\end{array}$ & $\begin{array}{c}\text { available } \\
\text { carbohydrates }\end{array}$ & $\begin{array}{c}\text { Calories } \\
\text { Kcal/100g }\end{array}$ \\
\hline Control 1 & $10.84 \mathrm{c}$ & $0.98 \mathrm{~d}$ & $0.77 \mathrm{e}$ & $0.85 \mathrm{~d}$ & $86.56 \mathrm{~b}$ & $396.45 \mathrm{~b}$ \\
& \pm 0.01 & \pm 0.01 & \pm 0.02 & \pm 0.02 & \pm 0.20 & \pm 0.78 \\
Control 2 & $7.60 \mathrm{f}$ & $1.17 \mathrm{c}$ & $0.75 \mathrm{e}$ & $0.25 \mathrm{f}$ & $90.23 \mathrm{a}$ & $398.10 \mathrm{a}$ \\
& \pm 0.02 & \pm 0.06 & \pm 0.03 & \pm 0.01 & \pm 0.07 & \pm 0.21 \\
Blend 3 & $10.52 \mathrm{e}$ & $1.30 \mathrm{~b}$ & $1.84 \mathrm{a}$ & $3.96 \mathrm{a}$ & $82.38 \mathrm{f}$ & $388.17 \mathrm{f}$ \\
& \pm 0.03 & \pm 0.10 & \pm 0.01 & \pm 0.07 & \pm 0.06 & \pm 0.16 \\
Blend 4 & $10.73 \mathrm{~d}$ & $1.32 \mathrm{~b}$ & $1.57 \mathrm{~b}$ & $3.19 \mathrm{~b}$ & $83.20 \mathrm{e}$ & $389.82 \mathrm{e}$ \\
& \pm 0.03 & \pm 0.02 & \pm 0.01 & \pm 0.04 & \pm 0.05 & \pm 0.25 \\
Blend 5 & $10.90 \mathrm{~b}$ & $1.32 \mathrm{~b}$ & $1.34 \mathrm{c}$ & $2.40 \mathrm{c}$ & $84.04 \mathrm{~d}$ & $391.79 \mathrm{~d}$ \\
& \pm 0.03 & \pm 0.06 & \pm 0.30 & \pm 0.01 & \pm 0.05 & \pm 0.20 \\
Blend 6 & $11.19 \mathrm{a}$ & $2.12 \mathrm{a}$ & $1.04 \mathrm{~d}$ & $0.84 \mathrm{e}$ & $84.81 \mathrm{c}$ & $393.33 \mathrm{c}$ \\
& \pm 0.11 & \pm 0.03 & \pm 0.02 & \pm 0.01 & \pm 0.01 & \pm 0.17
\end{tabular}

- Values followed by the same letter in columns are not significantly different at LSD at ( $\mathrm{p} \leq 0.05)$.

- Each value was an average of three determinations \pm standard deviation.

TABLE 9. Minerals content of flat bread prepared from rice flour, desichickpea and common beans.

\begin{tabular}{cccccccc}
\hline Minerals & \multicolumn{3}{c}{ Major elements } & \multicolumn{3}{c}{ Trace elements } \\
Samples & $\mathbf{C a}$ & $\mathbf{N a}$ & $\mathbf{M g}$ & $\mathbf{K}$ & $\mathbf{M n}$ & $\mathbf{F e}$ & $\mathbf{Z n}$ \\
\hline \multirow{2}{*}{ Control 1 } & $14.50 \mathrm{f}$ & $04.43 \mathrm{e}$ & $129 \mathrm{e}$ & $144 \mathrm{f}$ & $2.13 \mathrm{~cd}$ & $1.49 \mathrm{f}$ & $3.01 \mathrm{a}$ \\
& \pm 0.50 & \pm 0.11 & \pm 1.00 & \pm 1.00 & \pm 0.03 & \pm 0.01 & \pm 0.04 \\
Control 2 & $16.10 \mathrm{e}$ & $06.53 \mathrm{~d}$ & $139 \mathrm{~d}$ & $350.33 \mathrm{e}$ & $2.28 \mathrm{bcd}$ & $1.75 \mathrm{e}$ & $0.88 \mathrm{~d}$ \\
& \pm 0.36 & \pm 0.25 & \pm 1.00 & \pm 1.00 & \pm 0.02 & \pm 0.05 & \pm 0.02 \\
Blend 3 & $47.67 \mathrm{~d}$ & $10.20 \mathrm{c}$ & $144.58 \mathrm{a}$ & $522.33 \mathrm{~d}$ & $2.58 \mathrm{a}$ & $2.68 \mathrm{~d}$ & $1.22 \mathrm{c}$ \\
& \pm 0.25 & \pm 0.26 & \pm 0.50 & \pm 0.57 & \pm 0.23 & \pm 0.03 & \pm 0.06 \\
Blend 4 & $52.33 \mathrm{c}$ & $10.81 \mathrm{c}$ & $142.67 \mathrm{~b}$ & $553.83 \mathrm{c}$ & $2.40 \mathrm{ab}$ & $3.11 \mathrm{c}$ & $1.32 \mathrm{~b}$ \\
& \pm 0.57 & \pm 0.12 & \pm 0.58 & \pm 0.76 & \pm 0.10 & \pm 0.01 & \pm 0.04 \\
Blend 5 & $55.40 \mathrm{~b}$ & $14.42 \mathrm{~b}$ & $140 \mathrm{c}$ & $584.33 \mathrm{~b}$ & $2.33 \mathrm{bc}$ & $3.56 \mathrm{a}$ & $1.26 \mathrm{bc}$ \\
& \pm 0.46 & \pm 0.38 & \pm 0.58 & \pm 0.57 & \pm 0.06 & \pm 0.12 & \pm 0.02 \\
Blend 6 & $59.50 \mathrm{a}$ & $16.86 \mathrm{a}$ & $138 \mathrm{~d}$ & $616.57 \mathrm{a}$ & $2.08 \mathrm{~d}$ & $3.30 \mathrm{~b}$ & $1.23 \mathrm{c}$ \\
& \pm 0.50 & \pm 0.77 & \pm 0.58 & \pm 0.61 & \pm 0.16 & \pm 0.12 & \pm 0.06 \\
\hline
\end{tabular}

- Values followed by the same letter in columns are not significantly different at LSD at ( $\mathrm{p} \leq 0.05)$. -Each value was an average of three determinations \pm standard deviation.

TABLE 10. Sensory evaluation of flat bread.

\begin{tabular}{|c|c|c|c|c|c|c|}
\hline Samples & Taste & $\begin{array}{c}\text { Chewing } \\
\text { ability }\end{array}$ & Texture & Aroma & Color & Overall acceptability \\
\hline Controll & $9.47 \mathrm{a}$ & $9.27 \mathrm{a}$ & $8.73 a$ & $9.50 \mathrm{a}$ & $9.7 \mathrm{a}$ & $46.73 a$ \\
\hline \multirow{2}{*}{ Control2 } & $8.83 \mathrm{ab}$ & $8.83 \mathrm{abc}$ & $8.33 \mathrm{a}$ & $8.33 b$ & $8.66 b c$ & $43.00 \mathrm{~b}$ \\
\hline & \pm 0.29 & \pm 0.29 & \pm 0.57 & \pm 0.57 & \pm 0.57 & \pm 1.00 \\
\hline Blend3 & \pm 0.57 & \pm 0.15 & \pm 0.50 & \pm 0.57 & \pm 0.00 & \pm 0.91 \\
\hline \multirow{2}{*}{ Blend 4} & $8.00 \mathrm{~b}$ & $8.17 \mathrm{~d}$ & $8.30 \mathrm{a}$ & $8.16 \mathrm{~b}$ & $8.16 \mathrm{c}$ & $40.80 \mathrm{~d}$ \\
\hline & \pm 0.50 & \pm 0.29 & \pm 0.10 & \pm 0.28 & \pm 0.28 & \pm 0.10 \\
\hline Blend5 & $8.33 b$ & $9.00 \mathrm{~b}$ & $8.56 \mathrm{a}$ & $8.33 b$ & $8.83 b$ & $43.07 \mathrm{~b}$ \\
\hline
\end{tabular}

- Values followed by the same letter in columns are not significantly different at LSD at ( $p \leq 0.05)$.

- Each value was an average of three determinations \pm standard deviation. 


\section{Conclusion}

The obtained results in this study revealed that biscuits and flat bread were prepared using rice, desi chickpea and common beans at different levels. The final products were rich of protein, crude fiber and minerals with low caloric value. These products were a rich source of essential amino acids and minerals especially potassium, calcium, magnesium and iron. The sensory properties of prepared products were nearly similar of products prepared using wheat flour. These products were free of gluten therefore; they are very suitable for celiac patients. Finally, it could prepare some bakery products using materials free of gluten such as rice, desi chickpea and common beans flours with high quality that are suitable for celiac patients.

\section{References}

A.A.C.C. (2002) Approved Method of American Association of Cereal Chemists. Approved Methods of AACC Published by the American Association of Cereal Chemists. $13^{\text {th }}$ edition, St. Paul, Inc., Minnesota.

A.O.A.C. (2005) Official Methods of Analysis of the Association of Official Analytical Chemists. $18^{\text {th }}$ edition, Washington DC.

Abo-Allam, R.M. (2003) Data Statistical Analysis Using SPSS Program.1st ed., Publication for Cairo University, Egypt.

Akubor, P.I. and Ukwuru, M.U. (2003) Functional properties and biscuit making potential ofsoybean and cassava flour blends, Plant Foods for Human Nutrition, 58, 1-12.

Alsenaien, W. A.,Alamer, R. A., Tang, Z. X.,Albahrani, S. A.,AlGhannam, M. A. and Aleid, S. M. (2015) Substitution of Sugar with Dates Powder and Dates Syrup in Cookies Making. Advance Journal of Food Science and Technology., 8 (1), 8-13.

Aly, M.A. and Hinar, A.S. (2015) Gluten-Free Flat Bread and Biscuits Production by Cassava, Extruded Soy Protein and Pumpkin Powder Food and Nutrition Sciences, 6, 660-674.

Anjum, F.M., Pasha, I., Bugti, M.A. and Butt, M.S. (2007) Mineral composition of different varieties and their milling fractions. J. Agri. Sci., 44 (2), 332-336.

Barada, K., Biter, A., Mokadem, M.A., Hashash, J.G. and Green, P. (2010) Celiac disease in Middle Easrern and North African countries: a new burden.

J. Sus. Agric. Sci. Vol. 46, No. 1 (2020)
World Journal of Gastroenter Ology., 16(12), 1449-1457.

Bolarinwa, I.F., Abioye, A.O., Adeyanju, J.A. and Kareem, Z.O. (2016) Production and quality evaluation of biscuits Produced from malted sorghum,soy flour blends. Journal of Advances in Food Science and Technology, (3), 107-113.

Bose, D. and Shams, S. (2010) The effect of chickpea (Cicer arietinim) husk on the properties of cracker biscuits. Journal Bangladesh Agriculture University, 8 (1), 147-152.

Câmara, C.R.S.,Urrea, C.A. and Schlegel, V. (2013) Pinto Beans (Phaseolus vulgaris L.) as a Functional Food: Journal Agriculture., 3, 90-111.

Chauhan, A., Saxena, D.C. and Singh, S. (2016) Physical, textural, and sensory characteristics of wheat and amaranth flour blend cookies. Cogent Food and Agriculture., 2 (1), 1-8.

FAO (2004) Food and Agriculture Organization of United Nations.Economic and Social department. Available from FAOSTAT statistical database agriculture. Rome, Italy.

FAO (2008) Food and Agriculture Organization of United Nations.Economic and Social department. Available from FAOSTAT statistical database agriculture. Rome, Italy.

Ghribi, A. M., Maklouf1, M., Blecker, C., Attia, H. and Besbes, S. (2015) Nutritional and Compositional Study of Desi and Kabuli Chickpea (CicerArietinum L.)Flours from Tunisian Cultivars. J. Adv Food Technol Nutr Sci Open., 1 (2), 38-47.

Hamada, S., Suzuki, K., Aoki, N. and Suzuki, Y. (2013) Improvements in the Qualities of GlutenFree Bread after Using a Protease Obtained from Aspergillusoryzae. Journal of Cereal Science., 57, 91-97.

Hanee, M. A. and Yaseen, G. (2014) Novelty Formulas of Free Gluten Flat Bread for Celiac Disease Patients. World Journal of Medical Sciences. 11, 306-311.

Husby, S., Koletzko, I.T., Korponay, M. and Phillips, A. (2012) European society for pediatric gastroenterology and hematology. Nnutrition Guidelines for The Diagnosis of Celiac Disease., 54 (1), 136-159.

Ibrahim, O.S. (2017) Utilization of sorghum, broken rice and white beans flours for producing high nutritional value and high quality gluten-free 
biscuits. J. Current Sci. International., 6 (3), 670-683.

James, C.S. (1995) General Food Studies. In: Analytical Chemistry of Foods, Chapter 6, Blachie Academic \& Professional., 137-171.

Kalman, S.D. (2014) Amino Acid Composition of an Organic Brown Rice Protein Concentrate and Isolate Compared to Soy and Whey Concentrates and Isolates. J. Foods., 3, 394-402.

Kaur, M. and Singh, N. (2005) Studies on functional, thermal and pasting properties of flours from different chickpea (Cicer arietinum L.) cultivars. $J$. Food Chemistry, 91, 403-411.

Khattab, R.Y. and Arntfield, S.D. (2009) Nutritional quality of legume seeds as affected by some physical treatments 2. Antinutritional factors. $L W T$ - Food Science and Technology., 42, 1113-1118.

Kohajdova, Z., Karovicova, J. and Magala, M. (2011) Utilisation of chickpea flour for crackers production. J. Acta Chimica., 4 (2), 98-107.

Kute, T.C., Marlyne, M.,Wirba, L.Y., Amalene. S.H., Nkenmeni, D.C., Djote, W. B., Kansci, G., Fokou, E. and Fokam, D. P. (2018) Nutritional properties and nutrients chemical analysis of common beans seed. J. Biol Med. (3), 41-47.

Land, D.G. and Shepherd, R. (1988) Scaling and Ranking Methods. In: Piggott, J.R., (Ed.), Sensory Analysis of Foods Elsevier Applied Science, London., 155-185.

Motrena, S.G., Carvalho, M.J., Canada, J., Alvarenga, N.B., Lidon, F.C. and Elisa, B.P. (2011) Characterization of Gluten-Free Bread Prepared from Maize, Rice and Tapioca Flours Using the Hydrocolloid Seaweed Agar-Agar. Recent Research in Science and Technology, 3, 64-68.

Nouma, R.S. (2003) Sensory and physical evaluation of biscuits supplemented with soy flour, Pak J. Food., 13 (102), 45-48.
Omran, A. A. and Hussien, H. A. (2015) Production and Evaluation of Gluten-Free Cookies from Broken Rice and Sweet Potato. Advances in Food Sciences, 37 (4), 184-191.

Oyewole, O.B., Sanni, L.O. and Ogunjobi, M.A. (1996) Production of Biscuits Using Cassava Flour. Nigerian Food Journal, 14, 24-29.

Phimolsiripol, Y., Mukprasirt, A. and Schoenlechner, R. (2012) Quality Improvement of Rice-Based Gluten-Free Bread Using Different Dietary Fibre Fractions of Rice Bran. Journal of Cereal Science., 56, 389-395.

Prasad, K., Singh, Y. and Anil, A. (2012) Effects of Grinding Methods on the Characteristics of Pusa 1121 Rice Flour. Journal of Tropical Agriculture and Food Science, 40, 193-201.

Reynoso-Camacho, R., Ramos-Gomez, M. and Loarca-Pina, G. (2006) Bioactive components in common beans (Phaseolus vulgaris L.). J. Food Biotechnology., 81, 217-237.

Rezende, A.A., Pachecd, M.T., Solva, V.N. andFerreora, T.A. (2018) Nutritional and protein quality of dry Brazilian beans (Phaseolus vulgaris L.). Food Sci. Technol, Campinas., 38 (3), 421-427.

Roberfroid, M. (2002) Inulin and oligofructose as dietary fiber: a review of the evidence. Critical Reviews in Food Science and Nutrition, 41, 353362.

Roushdi, M., Ragaa, I. Zain, Osman, M.F. and Hassan, M.H. (2016) Effect of autoclaving treatment on increasing of rice and corn resistant starches $J$. Agric. Res. Kafr El-Sheikh Univ. 42, 976-996.

USAD (1986) Composition of foods legumes and legume and products.United states Department of Agriculture, Human Nutrition. 


\section{أعداد أغذية وظيفية خالية من الجلوتين لمرضى السيليك

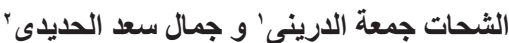

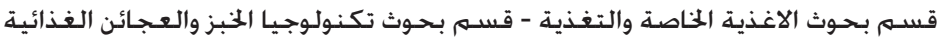

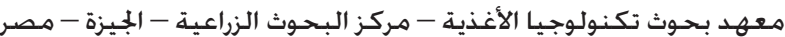

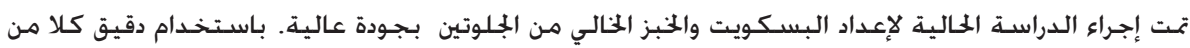

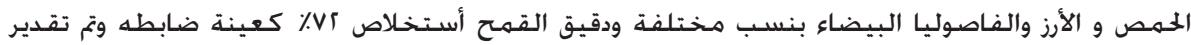

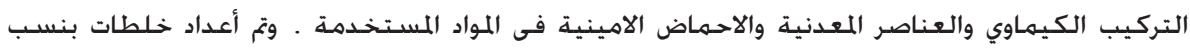

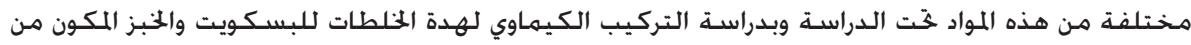

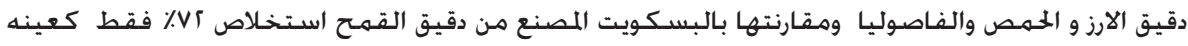

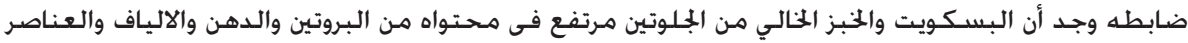

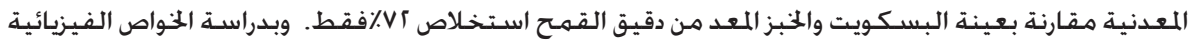

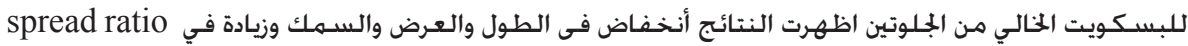

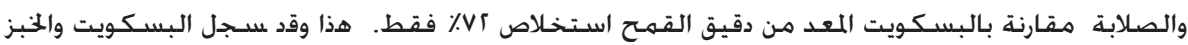

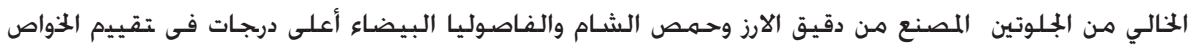

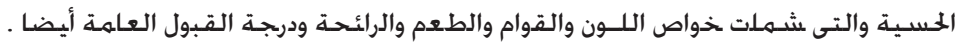

